\title{
Ficus septica Burm. f. Leaves Ethanolic Extract Triggered Apoptosis on 7,1 2-Dimethylbenz[a]anthracene-Induced Rat Mammary Carcinogenesis Qualitatively
}

\author{
Anindyajati*, Andita Pra Darma, Ika Nurzijah, Dita Brenna Septhea, \\ Agung Endro Nugroho \\ Cancer Chemoprevention Research Center, Faculty of Pharmacy, Universitas Gadjah Mada, Indonesia \\ Jalan Sekip Utara 55281 (Telp. 02746492662 Fax. 543120) \\ http://ccrc.farmasi.ugm.ac.id
}

\begin{abstract}
Ficus septica Burm. f. ethanolic extract (FEE) shows cytotoxic effects on several cancer cell lines. Our research aimed to investigate the effect of FEE on apoptosis induction and p53 expression against carcinogenesis of 7,12-Dimethylbenz[a]anthracene (DMBA)induced rat mammary. The research was conducted by comparing both apoptosis induction and p53 expression in DMBA-induced rats that were treated with FEE against control groups. Cells that undergo apoptosis were visualized by Double Staining method with acridine orange and ethidium bromide, while p53 expression was detected by IHC staining. Double staining results showed increased occurrence of apoptotic cells compared to the control groups. IHC staining of p53 did not show significant difference between treatment and control groups. However, FEE was able to repair morphology of cells undergoing carcinogenesis. Thus, we conclude that FEE has an anti-carcinogenic activity on DMBAinduced rat mammary through apoptosis induction without affecting p53 expression. Therefore, the ethanolic extract of Ficus Septica leaves is a potential chemo-preventive agent on breast cancer. Further study on its molecular mechanism needs to be explored.
\end{abstract}

Keywords: Ficus septica, breast cancer, 7,12-Dimethylbenz[a]anthracene, carcinogenesis, apoptosis, p53

\section{INTRODUCTION}

Nowadays, the incidence of cancer as a disease with a complex cellular pathophysiology is increasing (King, 2000). In the United States, there were 1.400 .000 incidences of cancer, $26 \%$ were breast cancer (Jemal, et al., 2008). The transformation of normal cell into malignant state is called carcinogenesis, which consists of four phases: initiation, promotion, progression, and metastases (Hanahan and Weinberg, 2011).

Cancer cells are able to avoid apoptosis, a programmed-cell-death, due to mutation of p53 (Hanahan and Weinberg, 2011). In order to suppress cancer growth, one existing mechanism of carcinogenesis inhibition is through apoptosis induction. This evidence may occur by the regulation of $\mathrm{Bcl}-2$ family proteins, both pro-apoptotic and antiapoptotic (Wyllie, et al., 2000). p53 induces the expression of pro-apoptotic proteins, which are
Bax and Bak, resulting in the release of cytochrome $\mathrm{C}$, leading cell to undergo apoptosis (Nakamura, 2003).

Ficus septica Burm. f. has been reported as a potential chemo-preventive agent. Phenantroindolicidine, an alkaloid found in Ficus septica, was proven to be potential against cancer (Staerk, et al., 2002). Chemopreventive agents are compounds that have the ability to prevent, to slow down, or to stop carcinogenesis (Tamimi, et al., 2005). Ficus septica Burm. f. ethanolic extract (FEE) exhibited the ability to trigger apoptosis and performed cytotoxic activity on T47D (breast cancer) cells with the $\mathrm{IC}_{50}$ value of $58 \mu \mathrm{g} / \mathrm{mL}$ (Nugroho, et al., 2011).

*Corresponding author e-mail: anindyajati.anin@yahoo.co.id 
Mubarok, et al. (2008) also figured out that Ficus septica was synergist with doxorubicin against MCF7 (breast cancer) cell line with the $\mathrm{IC}_{50}$ value of $6 \mu \mathrm{g} / \mathrm{mL}$ and was able to induce apoptosis by suppressing the expression of $\mathrm{Bcl}-$ 2.

Several in vitro studies on Ficus septica as a chemo-preventive agent have been conducted. This study aimed to observe FEE's ability to trigger apoptosis in vivo by increasing p53 expression. Observation was done on apoptosis and p53 expression of DMBAinduced rat mammary.

\section{MATERIALS AND METHODS}

\section{Ficus septica Extraction}

Ficus septica leaves were collected from Sleman, Yogyakarta, and determination was conducted in Laboratory of Pharmacognosy, Faculty of Pharmacy, Universitas Gadjah Mada. Fresh leaves were rinsed, dried, and powdered. Extraction was done by maceration with $70 \%$ ethanol (1:10). Filtrate was then concentrated using vacuum Rotary Evaporator.

\section{Animals}

Female Sprague Dawley Rats, aged 30 days, weighed from 86 to $112 \mathrm{~g}$ were purchased from Unit Pengembangan Hewan Percobaan Universitas Gadjah Mada. Animals were raised in ambient temperature $\left(25-30^{\circ} \mathrm{C}\right)$, fed with pellet and tap water.

\section{Chemicals}

7,12-Dimethylbenz [a]anthracene

(DMBA) (Sigma Chem. CO, St. Louis, MO), corn oil, $0.9 \% \mathrm{NaCl}$, anti p53 Ab-1/Clone Pab 240 (Neomarkers), acridine orange (Sigma), ethidium bromide (Fluka-Biochemika).

\section{Treatment}

There were 4 groups containing 5 rats in each group. Before being given to the test animals orally, DMBA and concentrated extract were dissolved in corn oil and 0.5\% CMC-Na, respectively. DMBA with the dosage of 20 $\mathrm{mg} / \mathrm{kgBW}$ were given in the first 5 weeks, twice a week, while FEE was given every day for 2 weeks, during the $9^{\text {th }}$ and $10^{\text {th }}$ week.

The first group (as positive control), treated with DMBA (DMBA control group). The second group was treated with DMBA and
FEE with the dosage of $750 \mathrm{mg} / \mathrm{kgBW}$ (treatment group). The third group was treated with FEE $750 \mathrm{mg} / \mathrm{kgBW}$ (FEE control), and the fourth group was treated only with CMC-Na (solvent extract control). Mammary sampling was done in the $10^{\text {th }}$ week.

\section{Observation of Apoptosis}

Apoptosis was detected with double staining method. Preparat of mammary tissue on poly-L-Lysine slide was incubated with acridin orange-ethidium bromide solution for 10 minutes in ambient temperature. Observation was done using fluorescence microscope (Zeiss MC 80). Cells that were viable will be observed as green fluorescence, while cells undergoing apoptosis appeared to be reddish-orange.

\section{Observation of p53 Expression}

Apoptosis was detected with IHC staining. Preparat of mammary tissue on polyL-Lysine slide was incubated with normal mouse serum for 5 minutes, followed by addition of primary antibody (monoclonal antibody anti-p53) for a night in $8^{\circ} \mathrm{C}$. After being washed with PBS for 3 times, biotinilated secondary antibody were given (incubation for 5 minutes) and the preparate was rewashed with PBS. DAB (3, 3'-diaminobenzidine) was used as substrate for biotinilated secondary antibody. Counterstaining with hematoxylin (3-4 minutes) was followed by rehydration and mounting. Observation was done microscopically. Positive p53 expression will appear to be brown.

\section{RESULTS AND DISCUSSION}

\section{Apoptosis Induction and p53 Expression}

Apoptosis is a programmed cell death resulting in morphological and biochemistry changes of a cell. One of the detection method provided is by double staining using acridine orange-ethidium bromide, that later will let us differ DNA fluorescence in viable cells and cells undergoing apoptosis. Analysis was done qualitatively by using a fluorescence microscope. As shown in Fig.1, apoptosis was detected in FEE-treated group and was negative in DMBA control group. Therefore, FEE with the dosage of $750 \mathrm{mg} / \mathrm{kgBW}$ triggered apoptosis in vivo. 


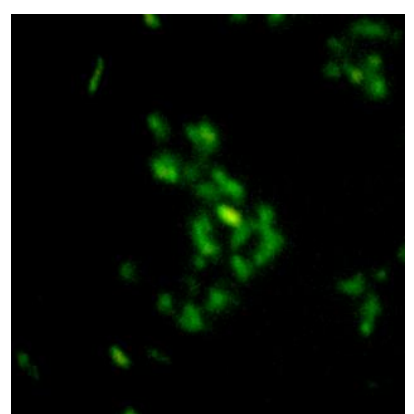

(A)

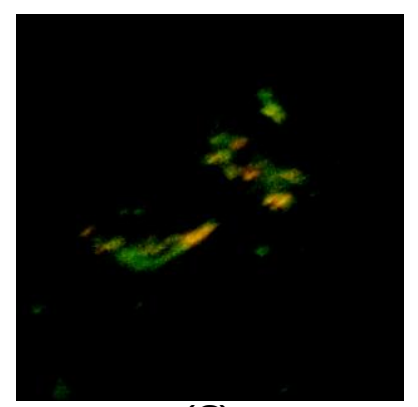

(C)

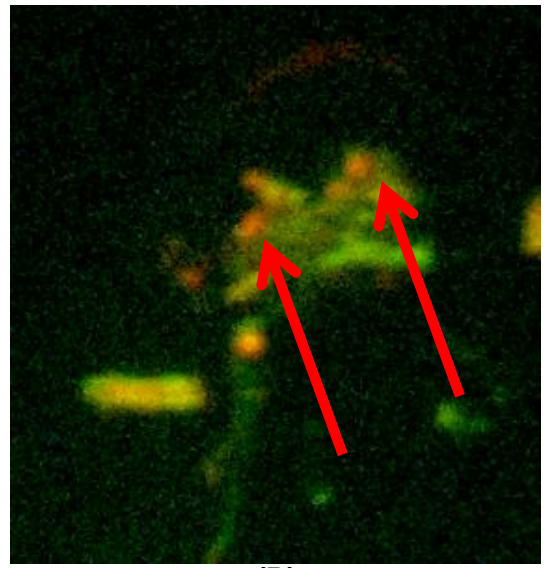

(B)

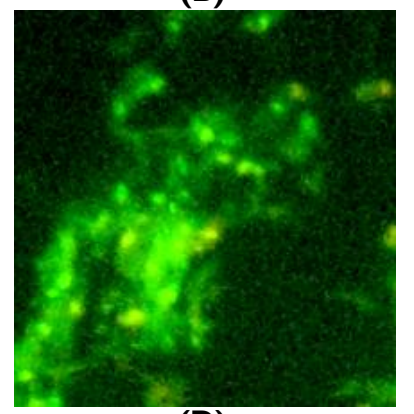

(D)

Figure I. Apoptosis detection in rats' mammary by Double Staining method (A) DMBA control group: apoptosis was negative in DMBA control group; (B) treatment group (DMBA and FEE): apoptosis was detected (orange fluorescence pointed with red arrows); (C) FEE control group; (D) CMC-Na control group 


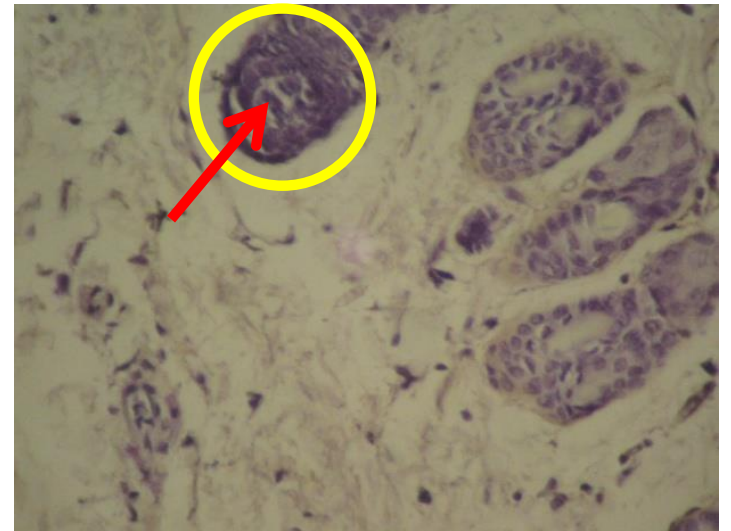

(A)

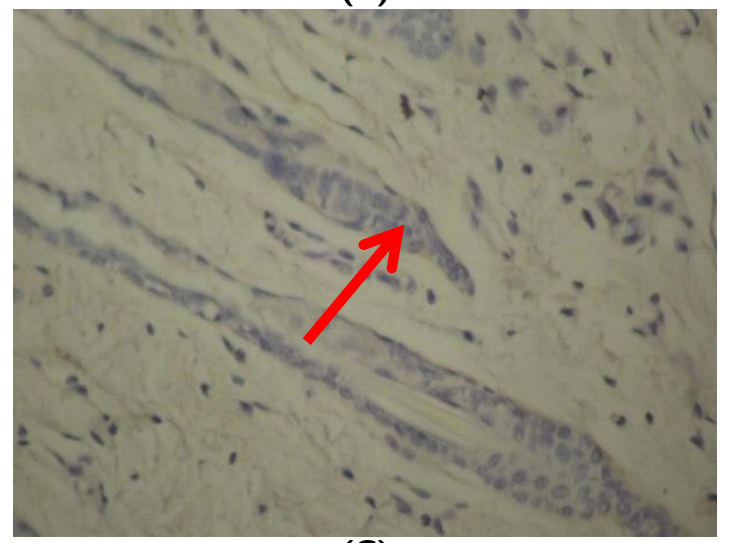

(C)

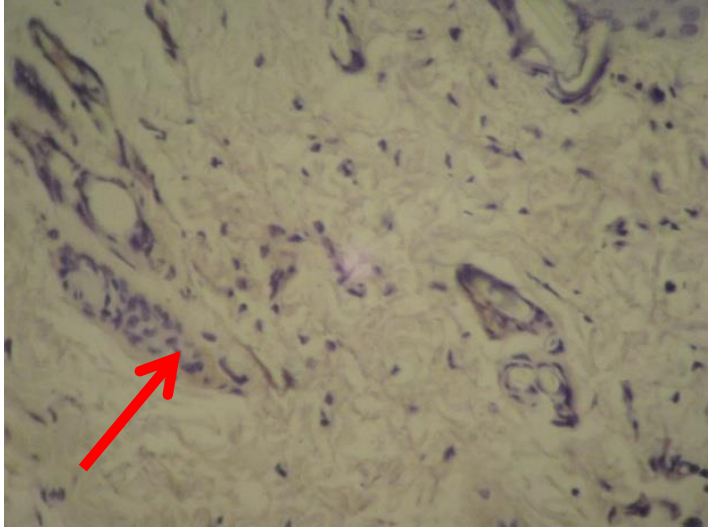

(B)

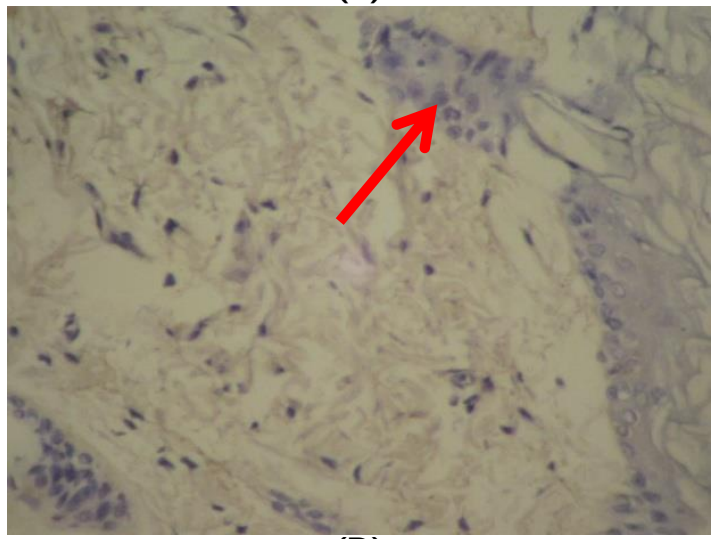

(D)

Figure 2. Expression of p53 in rats' mammary by IHC staining (a) DMBA control group: hyperproliferation in DMBA control groups is shown by yellow circle does not appear in control groups; (b) treated group (DMBA and FEE); (c) FEE control group; (d) CMC-Na control group; There was no significant difference of $\mathrm{p} 53$ expression between control and treated group (cytoplasm pointed with red arrows).

The second observation was done to know whether or not apoptosis induced by FEE is occurring following the increase of p53 expression, rendering to the fact that $\mathrm{p} 53$ takes an important role in apoptosis induction via p53-dependent pathway. This $\mathrm{p} 53$ protein also plays a role as a checkpoint control in both G1/S and G2/M phase. The detection was done by IHC staining which may identify specific protein in the cell or tissue by antibodylabeling. Fig.2 shows that there was no significant differences of p53 expression between control and treated group. Hence, FEE did not increase p53 expression in rats' mammary in vivo. However, repair of cell's morphology undergoing carcinogenesis by FEE was observed (hyper-proliferation in DMBA control groups is shown by green circle).

Since FEE triggered apoptosis without affecting p53 expression, the apoptosis induction was not via the p53-dependent pathway. The p53-independent pathway, known as the extrinsic pathway which is induced by activation of death receptors such as TNFR and FAS by proper ligands (TNF, FAS ligand). This pathway passes through the activation of caspase 8 which then cleaves Bid into tBid. Truncuted Bid induces pores formation in the outer membrane of mitochondrion, causing conformational change. This pore formation will lead to the accumulation of Bax in the outer layer of mitochondrion, inducing the release of apoptogenic proteins by mitochondrion such as Cytocrome C (Sun, et al., 2004). tBid is the active form of Bid that is in charge of turning the caspase pathway on leading the cell to undergo apoptosis.

This research concludes that Ficus septica Burm. f. ethanolic extract was able to trigger apoptosis without affecting the expression of $\mathrm{p} 53$ in rat mammary tissue induced by DMBA. Since this treatment did not 
affect p53 expression, the mechanism could be predicted that the apoptosis induction maybe through p53-independent pathway.

\section{ACKNOWLEDGEMENT}

This work was supported by grant from DP2M Dikti 2010 through Program Kreativitas Mahasiswa (PKM).

\section{REFERENCES}

Hanahan, D. and Weinberg, R.A., 20II, Hallmarks of Cancer: The Next Generation, Cell, I44(5), 646-674

Jemal, A., Rebecca Siegel, Elizabeth Ward, Yongping Hao, Jiaquan Xu, MD, Taylor Murray, and Michael J. Thun, Cancer Statistik 2008, CA Cancer J Clin 2008, 58, 7I-96 Amerika.

King, R.J.B., 2000, Cancer Biology, 2nd Ed., Pearson Eduation Limited, London.

Mubarok M.F., Sekti Dewi A., and Ainun W., 2008, Peningkatan Aktivitas Sitotoksik Doxorubicin terhadap Sel MCF-7 menggunakan Ekstrak Etanolik Daun Awarawar (Ficus septica Burm. f.), Prosiding KONGRES ILMIAH XVI ISFI
2008. ISBN: 978-979-95 I07-6-2. Penerbit: Ikatan Sarjana Farmasi Indonesia

Nugroho, A.E., Ikawati, M., Hermawan, A., Putri, D.D.P., and Meiyanto, E., Cytotoxic Effect of Ethanolic Extract Fractions of Indonesia Plant Ficus septica Burm. F. on Human Breast Cancer T47D cell lines, 201I, International Journal of Phytomedicine $\mathbf{3}$, 216-226.

Staerk, D., Lykkeberg, A.K, Christensen, J., Budnik, B.A., Abe, F. and Jaroszewski, J.W., 2002, In Vitro Cytotoxic Activity of Phenanthroindolizidine Alkaloids from Cynanchum vincetoxicum and Tylophora tanakae against DrugSensitive and Multidrug Resistant Cancer Cells, J. Nat. Prod., 65, 12991302.

Sun, S.Y., Hail, N., and Lotan, R., 2004, Apoptosis as a Novel Target for Cancer Chemoprevention, J Nat. Cancer Inst, 96, 662-672.

Tamimi, R.M., Lagiou, P., Adami, H., and Trichopoulo, D., 2002, Prospect for Chemopreventionof Cancer, Canc Contr J, 4(2), 55-64.

Wyllie, A., Donahue, V., Fischer, B.P., Hill, D., Kessey, J., and Manzow, 2000, Cell Death, Roche Diagnostic Cooporation, 2-64. 